he began his experiments on road-making, which were eventually to bring him fame if not fortune. It is not a little extraordinary, however, that his main work was done after reaching the age of sixty years, when he was made surveyor-general of roads to the Bristol Turnpike Trust. He resigned this position when sixty-nine, and two years later Parliament appointed him Surveyor-General of Roads. This position he held until his death at Dumcrieff House, Moffat, on November 26, 1836. At one time it is said he had no fewer than three hundred surveyors working under him. The importance of his work was fittingly commemorated at Ayr on October 30 last, when a bronze tablet erected by the Institution of Municipal and County Engineers was unveiled by Mr. Hore-Belisha, the Minister for Transport, and a paper on "John Loudon Macadam, Roadmaker" was read by Mr. G. S. Barry, the County Surveyor, Ayrshire.

\section{Memorial to the late Sir Walter Fletcher}

ON November 11, the subscribers to the Sir Waiter Fletcher Memorial Fund were invited by the Medical Research Council to view Miss Dora Clarke's portraitbust of the late Sir Walter Morley Fletcher, secretary of the Council from 1914 until 1933. The ceremony was held at the National Institute for Medical Research, Hampstead, in the library of which the bust is to be placed permanently. Lord Balfour of Burleigh, chairman of the Council, presided. The chief speakers were Prof. G. M. Trevelyan and Sir Frederick Gowland Hopkins, the former dealing mainly with the personal aspect and the latter with Fletcher's scientific and administrative work. Sir Henry Dale, director of the Institute, then accepted eustody of the bust. The total amount contributed to the Fund by more than five hundred separate subscribers is approximately $£ 2,300$. The remainder, after meeting the cost of the personal memorial, is being used for a Walter Fletcher Memorial Laboratory. This is being constructed at the Farm Laboratories of the National Institute at Mill Hill, and is to be used for research work in nutrition.

\section{Grassland of Great Britain}

AT a meeting of the Engineers Study Group on Economics held on November 10, Prof. R. G. Stapledon discussed methods of dealing with the problem of grassland in Great Britain. He exhibited a map of Wales, the result of a recent survey, and pointed out that there are only 16,000 acres of proper pastures (rye grass), although at least a third of the 153,000 acres under bracken is of high potential value. To make the best use of the $18,000,000$ acres of rough hill grazing ground in Great Britain, Prof. Stapledon considers that it is necessary for the State to acquire and develop it. This, he believes, would be economically feasible over a period of 25-50 years, beginning at once with an area of not less than 200,000 acres. Agriculturally, the potentialities of the hill land not above the $150 \mathrm{ft}$. contour (in all, more than $14,500,000$ acres) are enormous, at least 20 per cent of that area being amenable to radical improvement. Lowland grass could be used for drying and for wintering, and improved upland grass for summering, and the plough, oats and fatting crops everywhere. Roads and tracks should be constructed in connexion with land improvement and afforestation. Sir Richard Paget, who presided at the meeting, expressed his appreciation of the pioneer work of Prof. Stapledon, and Lord Northbourne, in opening the discussion, stressed the importance of preserving individual initiative.

\section{Temples and Caste in Travancore}

THE decision of the Maharajah of Travancore, announced by proclamation authorizing the opening of the temples controlled by the State to all Hindus, according to a Delhi dispatch in The Times of November 16, has been hailed by progressive opinion in India as "the greatest reform of Hinduism since Ramanuja's days". By this drastic action, which at once obliterates caste distinction in right of access to the sacred places of religion, and removes one of the most strongly resented marks of inferiority in the outcastes, the State of Travancore has opened a way to political unity which Hinduism at large would do well to accept as a guide and example. The exceptional position of the Rajah in relation to the State religion has endowed him with a power of initiative that was open to few others in India, and perhaps least of all to the British Raj ; but whether the example of Travancore will be followed elsewhere will doubtless depend in no small degree upon the religious and political reaction to so serious an innovation. It is said that conservative opinion has already criticized the reform as rash and unsound, while maintaining that the views of Hinduism outside Travancore should have been considered-a claim, of which, in view of past events, it would be difficult to vindicate the political wisdom. On the other hand, the Nationalists and leading members of the Congress, with Mr. Gandhi, have hastened to congratulate the head of the State of Travancore on his decision.

\section{Guide to Ancient Monuments}

Mr. ORMSBy-Gore's promise on relinquishing office as First Commissioner of Works to complete the manuscript of that part of the official guide to ancient monuments then in hand, has now been redeemed by the publication of the volume covering East Anglia and the Midlands ("Illustrated Regional Guides to Ancient Monuments under the Ownership or Guardianship of H.M. Office of Works", vol. 3, East Anglia and Midlands. By the Right Hon. W. Ormsby-Gore. London: H.M. Stationery Office. Pp. 72. 1s. net). In method of treatment of both the prehistoric and the historic sections this volume follows the plan of its predecessors; but matter of general application in the various periods, which has been given in the earlier volumes, has been omitted. Although it may be agreed that nothing can make a stronger appeal to the historic imagination than Stonehenge and Avebury, which have already been described, the present volume in no other respect falls below those already issued in the importance and interest of the monuments which it includes. As 
a source of information relating to the industries of neolithic man, Grime's Graves is without rival ; while the circle of Arbor Low in Derbyshire, and the megalithic barrows of the Cotswolds each hold a place in British prehistory, of which the importance needs no emphasis. It may be noted, however, that the latter are counted the oldest monuments under the guardianship of the Office of Works. Verulamium, since Dr. Mortimer Wheeler's excavations, is unique both as a British and a Romano-British site. In historic periods the abbeys of Shropshire and the castles, such as Framlingham, stand out among medieval buildings; while Kirby Hall, Northants, is one of the most important of the large country houses of Elizabethan and Jacobean times. For the first time, historic buildings belonging to the Crown appear. These are the Tower, Hampton Court, Kensington Palace, and the Chapter House of Westminster. Of the various periods into which English prehistory and history fall, the Saxon alone does not appear among the historic monuments under protection.

\section{Ethnology of the Far East}

THE authorities of the Raffles Museum, Singapore, have added a new series, to be known as Series B, to the Museum Bulletin. The present publication, which will now become Series A, hitherto has been devoted almost entirely to communications of a biological character. The new series will be anthropological, and for some time to come will be devoted largely to publication of the results of a scheme of research in the prehistory of the Malay Peninsula, for which the Carnegie Corporation of New York has voted a subvention extending over a period of three years. In the first issue of the new series are three reports on recent excavations-the first in Kedah by Mr. H. D. Collings, the second in a cave in Bukit Christamani by Mr. M. F. W. Tweedie, and the third on kitchen middens at Guak Kepeh, Wellesley Province, by Dr. P. V. van Stein Callenfels. The most important, as well as the longest, communication is from Dr. van Stein Callenfels, who, in "The Melanesian Civilization of Eastern Asia", contributes a detailed analysis of the Hoabinian stone age culture, so called from the early culture first distinguished in Tonkin, which he traces throughout the East so far as observed from China and Japan to Celebes, and analyses into three stages, in which he sees evidence for contacts between a people of a palæolithic type of culture with another in a protoneolithic stage. In incorporating the new evidence obtained under the present scheme in his analysis, and at the same time making use of the evidence afforded by earlier excavations in the Malay Peninsula, notwithstanding their defects in method, Dr. van Stein Callenfels also turns to the discussion of the position of Wadjak man, to whom he is inclined to assign a date later than the Pleistocene, but to regard him as a very old representative of the Melanesoid culture.

\section{The Consumption of Statistics}

Is his inaugural address on November 18 as president of the Royal Statistical Society, Lord Kennet urged the necessity for a more effective consumption of statisties. He affirmed that statisticsin the broad sense of the collection and methodical arrangement of facts-provide the one indispensable food from which the organs of Government can derive the motive power for the right conduct of the business of governing the nation. Decisions made without adequate statistical study on questions of the magnitude and complexity with which modern Governments have to deal, are not in the least likely to be even approximately correct, and the resulting policies and measures would be little better than the medicine-man's sympathetic magic carried out by incantation. Without doubt, then, the Government ought to be the most substantial consumers of statistics. If the Government consumes statisticsand it undoubtedly does to some extent both consume and digest them-the results of Government action seem to show that the metabolism is defective. What part of the organism is at fault? Lord Kennet classified the effective organs of Government as the Press, the wireless, the Civil Service, the Cabinet, the House of Commons, the voters at election time, the local authorities. Which of these is to blame? The fault must be directly attributed to the executive government, but the blame lies fundamentally with their masters, the people, whose national predilection is for 'muddling through', and who believe that scientific study has little practical value. Theory and practice are in reality not opposed but complementary to one another, and the widespread belief to the contrary is responsible for much of the mental lethargy which makes our conduct of affairs what it is-too often a fortuitous muddle.

\section{Coal Gas Research}

Ar the eighth Autumn Research Meeting of the Institution of Gas Engineers held in London on November 3-4, the papers showed current trends of thought in the gas industries. The thirty-ninth report of the Joint Research Committee of the Institution and the University of Leeds gave the first instalment of a study of the complete gasification of coal in oxygen-steam mixtures. Such a process, if successful, might make the industry less dependent on the choice of coal, and less would be required. At the same time it would have far-reaching consequences on the distributions of fuel. This report contained a study of the conditions within a fuel bed during gasification. Three papers dealt with the sulphur impurity in coal gas. Coal gas is the purest fuel in general use, but this very purity renders possible its use in flueless apparatus, and the small quantity of sulphur compounds present may become noticeable even if innocuous. The paper shows that the coal gas of the future may be purified of sulphur compounds to a degree hitherto unknown. The paper by H. Hollings on the formation and removal of gum in coal gas reveals the solution of a baffling problem which has arisen following the use of the practice of drying gas before distribution. Traces of unsaturated hydrocarbonsalmost inconceivably minute-condense or polymerize to form gummy substances which may cause trouble in appliances. The solution of this puzzle is 